\title{
Normal rainbow trout serum (RTS)-resistant variants of the infectious pancreatic necrosis virus (IPNV)-Jasper differ with respect to inhibition by RTS, serotype and cDNA sequence*
}

\author{
K. C. Park ${ }^{1,3, * *}$, S.-J. Lee ${ }^{2}$, P. W. Reno ${ }^{1}$ \\ ${ }^{1}$ Department of Microbiology and Coastal Oregon Marine Experimental Station, Hatfield Marine Science Center, \\ Oregon State University, 2030 SE Marine Science Drive, Newport, Oregon 97365, USA \\ ${ }^{2}$ Human Metabolism Section, Lab of Pharmacology and Chemistry, National Institute of Environmental Health Sciences, \\ National Institutes of Health, 111 Alexander Drive, MD C3-01, PO Box 12233, Research Triangle Park, \\ North Carolina 27709, USA \\ ${ }^{3}$ Present address: Institute for Marine Biosciences, National Research Council Canada, 1411 Oxford Street, Halifax, \\ Nova Scotia B3H 3Z1, Canada
}

\begin{abstract}
In order to determine if the infectious pancreatic necrosis virus isolate IPNV-Jasper (JaATCC) is homogeneous or heterogeneous with respect to inhibition by normal rainbow trout serum (RTS), 50 clones were tested for sensitivity to RTS. The initial isolate was very sensitive to RTS, losing from $10^{4}$ to $10^{8} 50 \%$ tissue culture infection dose $\left(\mathrm{TCID}_{50}\right) \mathrm{ml}^{-1}$ with a 1:100 dilution of RTS. The sensitivity of the clones ranged from highly sensitive to completely resistant (0 to $10^{8} \mathrm{TCID}_{50} \mathrm{ml}^{-1} \mathrm{reduc}^{-}$ tion). Eight percent of clones (4/50) were very sensitive to RTS (Ja-S) and $84 \%$ of clones (42/50) showed a mid-range of sensitivity to RTS. The final $8 \%$ of clones (4/50) were resistant to RTS (Ja-R). Enzyme immunodot assay revealed that Ja-S clones showed a monoclonal reaction identical to the parents, Ja-ATCC; however, Ja-R clones differed by several epitopes from the parental strain. Analysis of Ja-S and Ja-R revealed that there were significant differences in their nucleic acid sequences for the capsid protein VP2. These 2 strains shared 80.7 and $86.5 \%$ identity in nucleic acid and in amino acid sequences, respectively. Ja-S had 99.7 and $91.0 \%$ identity in nucleic acid sequences, and 99.5 and $95.9 \%$ in amino acid sequences with Ja-ATCC and Jasper-Dobos (Ja-D), respectively, while Ja-R showed 80.6 and $79.8 \%$ identity in nucleic acid sequences and 86.5 and $87.0 \%$ in amino acid sequences with Ja-ATCC and Ja-D, respectively. In conclusion, the Ja-ATCC population was heterogeneous in terms of RTS sensitivity, serotype and cDNA sequences from the VP2 coding region.
\end{abstract}

KEY WORDS: IPNV-Jasper variants · RTS inhibition · Serotype $\cdot$ cDNA sequence

\section{INTRODUCTION}

Infectious pancreatic necrosis virus (IPNV) belongs to the family Birnaviridae (Dobos et al. 1979) and is an agent of an acute, contagious fish disease causing high mortality not only in juvenile salmonids but also in non-

*The nucleotide sequences reported in this paper have been deposited in the GenBank data base (Accession No: AF399925 for Ja-S and AF399926 for Ja-R). salmonid fishes (Reno 1999). IPNV has 2 segments of double-stranded RNA: segments A $\left(2.5 \times 10^{6} \mathrm{Da}\right)$ and $\mathrm{B}$ $\left(2.3 \times 10^{6} \mathrm{Da}\right)$. The longer one encodes a $106 \mathrm{kDa}$ polyprotein that is cotranslationally cleaved by a viral protease (NS or VP4, $29 \mathrm{kDa}$ ) into 2 proteins, pVP2 (62 kDa) and VP3 (31 kDa) (MacDonald \& Dobos 1981, Mertens \& Dobos 1982, Duncan et al. 1987). VP3 was thought to be an internal protein of the virus (Dobos \& Rowe 1977), but at least a portion of VP3 is exposed on the surface since it reacts with a number of monoclonal 
antibodies (Caswell-Reno et al. 1989). pVP2 is further processed during viral maturation into VP2, which is a major external protein and responsible for the reaction of type-specific neutralizing monoclonal antibodies (Dobos et al. 1977, Nicholson 1993). A universal, groupspecific epitope has been reported to be located near the amino terminus of VP2, whereas the polypeptide responsible for a serotype-specific epitope has been mapped in the middle of VP2 (Dobos 1995). It has been reported that an anti-IPNV inhibitor, called ' $6 \mathrm{~S}$ inhibitor or RTS inhibitor', is present in rainbow trout serum (RTS) unexposed to IPNV (Vestergard-Jørgensen 1973, Dorson \& de Kinkelin 1974). The inhibitor has a sedimentation coefficient of approximately $6 \mathrm{~S}$ by ultracentrifugation and is not thought to be an antibody as inhibition was not dependent on the specific serotypes of IPNV (Macdonald \& Gower 1981, Ögüt 1995). Park (2000) suggested that it is not interferon due to its strongest inhibition activity at a molecular weight of approximately $150 \mathrm{kDa}$. It has also been demonstrated that IPNV can be directly affected by the RTS inhibitor before viral attachment and that pretreatment of tissue culture cells with RTS does not provide protection against subsequent viral infections (Kelly \& Nielson 1985, Park 2000). This suggests that inhibition does not result from the stimulation of tissue culture cells to release cytokines. Not all virus isolates tested were inhibited by RTS and the inhibition was not dependent on the specific serotypes of IPNV (Macdonald \& Gower 1981, Ögüt 1995). Cell culture-adapted virus strains were more susceptible to RTS than were wild type virus (Dorson \& de Kinkelin 1974, Hill \& Dixon 1977, Dorson et al. 1978). It has also been reported by some researchers that RTS sensitivity was correlated with virulence of IPNV and that virulence was changed by cell passage (Hill \& Dixon 1977, Hill 1982, Ögüt 1995). The RTS sensitivity of IPNV is also dependent on the cell line in which the virus replicates. It has been reported that IPNV sensitivity to RTS was increased rapidly with multiple viral passages in a cyprinid cell line (EPC) compared to RTG-2 or bluegill fry (BF) cell lines (Hill \& Dixon 1977) but decreased with passage in the Chinook salmon embryo (CHSE)-214 cell line (Park 2000).

In our previous experiments, we found much variation in the sensitivity of IPNV to RTS inhibitory activity even though we used the same RTS source, the same stock of virus and the same host cell condition (confluent) (Park 2000). In experiments using a member of the $\mathrm{A}_{1}$ serotype (IPNV-Buhl), we found that sensitivity was altered after 5 passages in RTG-2 cells (Park 2000). Sequencing of the sensitive and resistant variants revealed genetic differences in the VP2 region of sensitive and resistant variants, but not in VP3. Therefore, we questioned whether the virus population was heterogeneous in terms of RTS sensitivity. At present, no information is available about whether virus clones have different RTS sensitivity and different genetic information. Therefore, in this work, we first cloned an RTS-sensitive strain of IPNV originally isolated from trout in a facility in Jasper-Alberta, Canada (Hill \& Way 1995) and tested the progeny for RTS sensitivity. Second, the epitope pattern on VP2 and VP3 of clones with 2 different sensitivities was determined. Third, the cDNA sequences of the VP2 region of 2 strains of IPNV-Jasper, highly RTS-sensitive (Ja-S) or RTSresistent (Ja-R), were compared.

\section{MATERIALS AND METHODS}

Virus. The IPNV-Jasper isolate (ATCC VR-1325), JaATCC, used in this study belongs to serotype $\mathrm{A}_{9}$ (Hill \& Way 1995). This virus was originally isolated from diseased brook trout Salvelinus fontinalis at the Maligne River Hatchery, Alberta, Canada (Yamamoto 1974). It was kindly provided by Dr. B. Nicholson, University of Maine, Orono, ME, USA, who originally received it as a donation from Dr. Barry Hill (Department of Fisheries and Food [DAFF], Weymouth, UK). The virus has been passaged for $20 \mathrm{yr}$ in the laboratory. Brook trout were obtained from Wizard Falls Hatchery, Camp Sherman, OR. IPNV has not been detected at this hatchery since 1976. The fish were held at the laboratory for Fish Disease Research at Hatfield Marine Science Center, Newport, OR in dechlorinated city water. Prior to use in these experiments, the virus was passaged 2 times through brook trout fry by immersion in water containing $10^{4} \mathrm{TCID}_{50}$ $\mathrm{ml}^{-1}$ for $5 \mathrm{~h}$ at $14^{\circ} \mathrm{C}$, isolated in CHSE-214 cells (Lannan et al. 1984) and frozen until use.

Isolation of clones sensitive or resistant to RTS. IPNV-Jasper $\left(10^{7} \mathrm{TCID}_{50} \mathrm{ml}^{-1}\right)$ was serially diluted to $10^{1} \mathrm{TCID}_{50} \mathrm{ml}^{-1}$ and $0.1 \mathrm{ml}$ of the final dilution was inoculated into 96 wells of each of 15 replicate 96 -well plates. Fifty virus clones were isolated from 96-well plates showing CPE in fewer than 5 wells. The virus contained in these wells had a high probability of arising from a single virus. The isolated clones were tested for sensitivity to RTS in vitro as described below. Aliquots of isolated clones were kept in liquid nitrogen for later enzyme immunodot assay and sequencing.

In vitro virus sensitivity to $R$ TS. The RTG- 2 cells (Wolf \& Quimby 1962) were propagated in 24 -well plates as described by Caswell-Reno et al. (1989). In this experiment, 3 types of media were used: Eagle's Minimum Essential Medium (MEM) without serum (MEM-0); MEM $+10 \%$ fetal bovine serum (MEM-10); MEM + $10 \%$ fetal bovine serum $+1 \%$ RTS (MEM-RTS). Two wells were prepared for each clone; one well was for MEM-RTS and the other one was for MEM-10. Virus was diluted with MEM-10 or MEM-RTS to give a final virus concentration 
of $10^{4} \mathrm{TCID}_{50} \mathrm{ml}^{-1}$. A total of $100 \mu \mathrm{l}$ of diluted virus were added onto a confluent monolayer of cells in each well and incubated at room temperature for $2 \mathrm{~h}$. After the incubation time, the inoculated monolayers were washed 3 times with MEM- 0 and then $1 \mathrm{ml}$ of either MEM-10 or MEM-RTS was added. Uninoculated controls were treated with either medium, MEM-10 or MEM-RTS, as appropriate. Cells were incubated at $18^{\circ} \mathrm{C}$ for $7 \mathrm{~d}$ in an incubator to which $5 \% \mathrm{CO}_{2}$ was supplied. The level of cytopathic effect (CPE) was monitored daily and scaled from 0 (no CPE) to 4 (complete CPE) on an ordinal scale. On the 7th day after exposure, cell culture supernatant from each well was harvested, pooled and held in liquid nitrogen until they were titrated.

Virus titration. CHSE-214 cells (Lannan et al. 1984) were grown with MEM-10 in 96-well plates. The endpoint dilution method as described in Caswell-Reno et al. (1986) was used for virus titration. Virus samples were serially diluted 10-fold with MEM-0 and then $100 \mu \mathrm{l}$ of each of diluted virus suspension were added to each of 4 wells of a 96-well plate (Lannan et al. 1984). After incubation at $18^{\circ} \mathrm{C}$ for $7 \mathrm{~d}$, wells showing CPE were counted to determine $50 \%$ tissue culture infectious dose $\left(\right.$ TCID $_{50} \mathrm{ml}^{-1}$ ) (Spearman 1908).

RT-PCR. Viral RNA was extracted from 2 types of IPNV-Jasper clones, Ja-S or Ja-R, using TRIzol reagent according to the manufacturer's instructions (Life Technologies) as described earlier (Lee et al. 1998). Primers (F31 and R1212), shown in Table 1, were designed based on published sequences of the cDNAs of genomic segment A of the Jasper-Dobas (Ja-D) clone (Duncan \& Dobos 1986). Primers for PCR and sequencing were constructed at the Oregon State University (OSU) Center for Gene Research. Extracted RNA was diluted in RNase, DNase-free water to a concentration of $100 \mathrm{ng} \mathrm{ul}^{-1} \mathrm{RNA}$ and heated at $95^{\circ} \mathrm{C}$ for $5 \mathrm{~min}$, and placed on ice for $2 \mathrm{~min}$. The reaction components for the first-strand synthesis included viral RNA (200 ng), R1212 primer (200 pmol), a reaction buffer (final reaction contains $50 \mathrm{mM}$ Tris- $\mathrm{HCl}$, $\mathrm{pH} 8.3,30 \mathrm{mM} \mathrm{KCl}, 8 \mathrm{mM} \mathrm{MgCl}_{2}$, $1 \mathrm{mM}$ dithiothretital [DTT]), each dNTP at $2 \mathrm{mM}$, RNasin (40 units) and Moloney murine leukemia virus (MMLV) reverse transcriptase (400 units) in $50 \mu \mathrm{l}$ reaction. The $\mathrm{RT}$ reaction was performed at $37^{\circ} \mathrm{C}$ for $1 \mathrm{~h}$. The cDNA was stored at $-70^{\circ} \mathrm{C}$. Ten $\mu \mathrm{l}$ of cDNA $\left(150 \mathrm{ng}^{-1} \mathrm{l}^{-1}\right)$ was heated at $95^{\circ} \mathrm{C}$ for $5 \mathrm{~min}$, then cooled on ice and briefly centrifuged at $10000 \times g$. The PCR contained primers at 10 pmol each (R1212 and F31), each dNTP at $2.5 \mathrm{mM}, \mathrm{CDNA}$ (300 ng), $15 \mathrm{mM} \mathrm{MgCl}_{2}$ and PLATINUM Taq DNA polymerase at $2.5 \mathrm{U}$ (Life Technologies). Amplification was performed in a Programmable Thermal Controller (PCT100, MJ Research). PCR cycling parameters included initial denaturation of $4 \mathrm{~min}$ at $94^{\circ} \mathrm{C}$ (1 cycle), 35 cycles each of; a denaturation/annealing/extention $\left(94^{\circ} \mathrm{C}, 1 \mathrm{~min} /\right.$ $60^{\circ} \mathrm{C}, 1 \mathrm{~min} / 72^{\circ} \mathrm{C}, 2 \mathrm{~min}$ ) and a final extention at $72^{\circ} \mathrm{C}$ for $10 \mathrm{~min}$.

Purification of PCR products and cDNA cloning. Twenty $\mu$ of each of the RT-PCR products were analyzed by electrophoresis through a $1 \%(\mathrm{w} / \mathrm{v})$ agarose gel containing ethidium bromide $\left(0.5 \mu \mathrm{g} \mathrm{ml}^{-1}\right)$ in TAE buffer ( $40 \mathrm{mM}$ Tris, $20 \mathrm{mM}$ acetic acid, $2 \mathrm{mM}$ EDTA). The gel was electrophoresed at $75 \mathrm{~V}$ for $1.5 \mathrm{~h}$ and visualized with a UV light. The DNA band of expected size $(1.2 \mathrm{~kb})$ was excised and purified using the QIAquick Gel Extraction Kit (QIAGEN) according to the manufacturer's protocol. Purified PCR products were cloned using TOPO TA Cloning kit (Invitrogen) according to the manufacturer's instructions. A QIAprep Spin Miniprep Kit (QIAGEN) was used to purify plasmid DNA from transformed Escherichia coli cells.

Sequencing and phylogenetic analysis. Sequencing of the DNA was carried out at OSU Center for Gene Research using an automatic DNA sequencer (ABI PRISM Model 377). Each base in the sequence was determined at least 3 times in both directions using synthetic oligonucleotide primers (Table 1) designed from determined nucleotide sequences. Chromatograms (ABI PRISMS) of sequenced data were analyzed and assembled by the use of the MacVector software and nucleotide discrepancies among sequence replicates were determined by majority consensus. The nucleotide sequence was translated into amino acids using MacVector software. The nucleotide sequences of 2 strain types of IPNV-Jasper clones in this paper have been deposited in GenBank with the following accession numbers: Ja-S, AF399925; Ja-R, AF399926. The similarity and phylogenetic relationships among these strains and the other 14 IPNV strains available in GenBank were analyzed by the Clustal method with DNASTAR MEGALIGN program

Table 1. Primers for RT-PCR and cDNA sequencing. Map positions of the primers are based on the sequence of segment A of Jasper (Duncan \& Dobos 1986): position 31 in this paper corresponds to position 151 of segment A of Jasper

\begin{tabular}{|lccl|}
\hline $\begin{array}{l}\text { Primer } \\
\text { name }\end{array}$ & Orientation & Position $^{\mathrm{a}}$ & Sequence (5' to 3') \\
\hline F31 & & & \\
F37 & Sense & $31-53$ & TTGAGATCCATTATGCTTCCCGA \\
R148 & Antisense & $148-125$ & TCCATTATGCTTCCCGAGAATGGA \\
F417 & Sense & $417-437$ & CAGCTTGATGTCCCTGACAAC \\
R669 & Antisense & $669-649$ & TGTTGGGGTCCCGGTTGCCAT \\
F735 & Sense & $735-754$ & GCTAGAAGCCAAACCCGCCA \\
R1208 & Antisense & $1208-1182$ & AGGATCATCTTGGCATAGTTAGGCCC \\
R1212 & Antisense & $1212-1190$ & GGACAGGATCATCTTGGCATAGT \\
aMap positions of the primers used for RT-PCR
\end{tabular}


(Lasergene). The strains utilized in this analysis have the accession numbers: Ja-D, NC001915; Ja-ATCC, AF342735; N1, D00701; He, AF342730; ASV, AY026490; C1, AF342732; EEV, AY026486; VR-299, AF343572; WB, AF342727; C2, AF342733; Sp, AF342728; Ab, AF342729; C3, AF342734; Te, AF342731.

Protein structure analysis. Protein composition and antigenic index (James-Wolf method) of amino acid sequences were analyzed using the DNASTAR Protean program (Lasergene). Hydropathic plots for 2 strains were conducted by the Kyte-Doolittle method using the DNASTAR Protean program (Lasergene) and more detailed information was obtained using the SeqView program.

Enzyme immunodot assay. To determine whether Ja-S and Ja-R clones of IPNV-Jasper (Ja-ATCC) have different epitopes, an enzyme immunodot assay was performed for the parent virus population (Ja-ATCC), cloned Ja-S and cloned Ja-R following the procedure of Caswell-Reno et al. (1989). As positive controls, 6 serotype isolates including Canada 1 were used. A total of $100 \mu \mathrm{l}$ of each virus $\left(10^{7} \mathrm{TCID}_{50} \mathrm{ml}^{-1}\right)$ was added for the reaction with monoclonal antibodies. Supernatant collected from uninfected CHSE-214 cell culture was used as a negative-control antigen.

\section{RESULTS}

\section{In vitro virus sensitivity to $\mathrm{RTS}$}

In order to determine whether IPNV-Jasper (JaATCC) clones are homogeneous or heterogeneous in terms of RTS sensitivity, 50 clones were isolated from a virus population which had been passaged twice through brook trout, then once in CHSE-214 cells and tested for RTS sensitivity. The RTS sensitivity of the clones ranged from highly sensitive to resistant. The parent isolate (Ja-ATCC) was extremely sensitive to RTS, losing $10^{8} \mathrm{TCID}_{50} \mathrm{ml}^{-1}$ after treatment. Eight percent of clones were also very sensitive (Ja-S) showing no CPE during $7 \mathrm{~d}$ incubation in the presence of RTS and were inhibited as high as $10^{-4.8} \mathrm{TCID}_{50} \mathrm{ml}^{-1}$ reduction. Eighty-four percent of clones showed a mid-range of RTS sensitivity. CPE levels of these clones (as measured on an ordinal scale of 0 to 3 ) in the presence of RTS were 1 to 2, while it was 3 in the absence of RTS. The mean inhibition level was $10^{-2.3} \mathrm{TCID}_{50} \mathrm{ml}^{-1}$. Eight percent of clones were resistant to inactivation by RTS (Ja-R). They were not significantly inhibited by RTS (mean $10^{-0.8} \mathrm{TCID}_{50} \mathrm{ml}^{-1}$ reduction). The level or intensity of CPE-development with these clones was the same in the presence or absence of RTS (3 on our scale). CPE had developed by the second day postinfection in these clones.

\section{Nucleotide and deduced amino acid sequences}

The conserved initiation codon (ATG) of the large open reading frame (ORF) as published by Duncan \& Dobos (1986) is defined as position 1 in our sequence analysis. Our sequences span the region from position 31 to position 1212 . There was an $80.7 \%$ nucleotide identity between Ja-S and Ja-R. Upon comparison of these data with information on IPNV-Jasper strain (JaD) (Duncan \& Dobos 1986) and IPNV-Jasper (ATCC VR-1325) (Ja-ATCC) (Blake et al. 2001), we obtained a $99.7 \%$ nucleotide identity for Ja-S and $80.6 \%$ identity for Ja-R when compared to Ja-ATCC. When compared to Ja-D, both Ja-S and Ja-R had slightly lower nucleotide identities (91.0 and $79.9 \%$, respectively). With respect to percent nucleotide divergence, Ja-S showed 0.3, 9.0 and $19.3 \%$ divergence from Ja-ATCC, Ja-D and Ja-R, respectively. Our sequence for Ja-R showed a $19.4 \%$ divergence from Ja-ATCC and a $20.2 \%$ divergence from Ja-D.

The results of our comparison of the deduced amino acid sequences of Ja-S and Ja-R to each other, as well as to published sequences for the parent strain (JaATCC) and other strains are given in Fig. 1 \& Table 2. There was an $86.5 \%$ amino acid identity between Ja-S and Ja-R. Our RTS-sensitive group of clones (Ja-S) had a higher amino acid identity to Ja-ATCC (99.55\%) than to Ja-D (95.9\%), West Buxton (ATCC VR-877) $(95.9 \%)$ or VR-299 (ATCC VR-299) (95.9\%). With respect to percent amino acid divergence, Ja-S showed a divergence of $0.5 \%$ with Ja-ATCC, $4.2 \%$ with Ja-D and $14.9 \%$ with Ja-R (Table 2). It is not surprising that our phylogenetic analysis places Ja-S within a clade formed by Ja-D, VR-229, WB and JaATCC (Fig. 2).

Our resistant group (Ja-R) showed relatively low amino acid identities with Ja-ATCC (86.5\%) and Ja-D $(87.0 \%)$, and higher amino acid identities with ASV $(95.9 \%)$ and C1 $(96.7 \%)$. With respect to percent amino acid divergence, Ja-R showed a divergence of $14.9 \%$ with Ja-ATCC and $14.3 \%$ with Ja-D. The results of our phylogenetic analysis places Ja-R within a clade formed by ASV and C1.

\section{Protein structure analysis}

The predicted molecular weights of the proteins encoded by these sequences were 41836 Da for Ja-S and 41723 Da for Ja-R. Both proteins had the same predicted isoelectric point of 5.0. Further analysis of these proteins revealed that Ja-S had 32.5 and $32.2 \%$ of polar residues and hydrophobic residues, respectively, while Ja-R had 32.5 and $31.7 \%$, respectively. Comparison of the hydrophilic plots of the 2 strains 


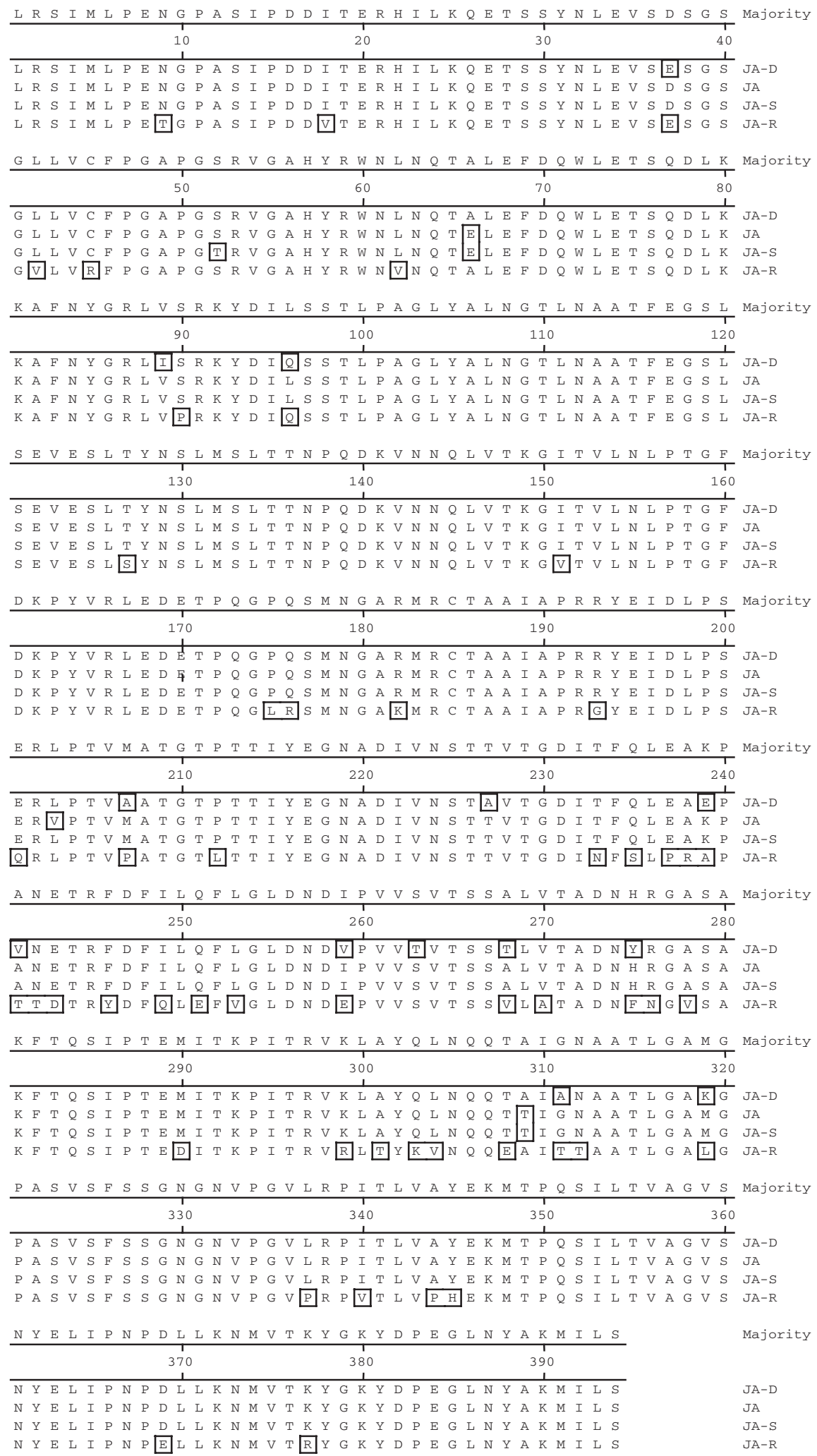

Fig. 1. Multiple alignment of deduced amino acid sequences of the $1182 \mathrm{bp}$ cDNA fragment representing most of the VP2 protein of IPNV. Boxes indicate differences with the consensus. Each isolate is indicated as follows: JA-D = Jasper isolate (NC001915; Duncan \& Dobos 1986); JA = Jasper-ATCC (AF342735; Blake et al. 2001); JA-S (AF399925) = Jasper isolate which is sensitive to RTS; JA-R (AF399926) = Jasper isolate which is resistant to RTS 
revealed marked differences in hydrophilic region found in Ja-S and Ja-R: 64-69 (R), 74-75 (S), 258-259 (S), 276-278 (R), 340-343 (R) (Fig. 3). At these positions, only strain Ja-S had at least 3 consecutive hydrophilic residues, while Ja-R did not show any hydrophilic residues. The difference between hydrophilic regions on the protein of the 2 strains was closely related to the estimated antigenic difference between the 2 clones (Fig. 3). Significant antigenic differences were found at these positions: 61-70, 126-130 and 231-340.

\section{Enzyme immunodot assay}

Differences in the monoclonal antibody reaction profile were determined for parent Ja-ATCC, Ja-S and Ja-R (Table 3). The parent Ja-ATCC and Ja-S showed identical epitope patterns with a panel of 11 anti-IPNV MAbs having positive reactions with the monoclonal antibodies AS-1, W-1, W-2, W-3, W-4, W-5, E-1 and E5. The monoclonal antibody reaction profile was significantly different for Ja-R with positive reactions seen with the monoclonal antibodies AS-1, E-1, E-5 and E-6.

\section{DISCUSSION}

The use of modern molecular techniques has demonstrated that populations of sero- logically identical RNA viruses are extremely heterogeneous (Steinhauer \& Holland 1987, Steinhauer et al. 1989). This extreme heterogeneity of RNA virus has also been reported among clones from single isolates of foot-and-mouth disease viruses (Domingo et al. 1980, Schiappacassi et al. 1995). This is thought to be due to an inefficient nucleic acid repair system that retains transcription errors at a high rate compared to those in DNA virus. Despite heterogeneity within virus populations, termed quasispecies, high mutation rates

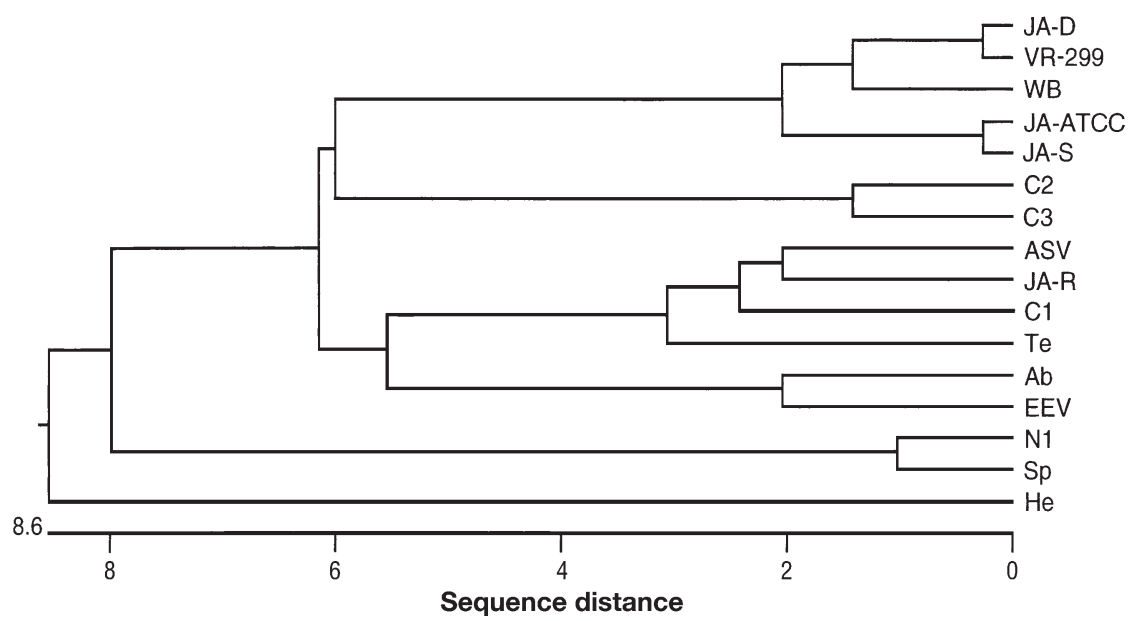

Fig. 2. Phylogenetic tree of selected aquatic birnaviruses based on deduced amino acid sequences of the 1179 bp cDNA fragment encoding most of VP2. GenBank accession numbers of 16 IPNV used for phylogenetic analysis as follows: Ja-S (AF399925); Ja-R (AF399926); Ja-D (NC001915); Ja-ATCC (AF342735); N1 (D00701); He (AF342730); ASV (AY026490); C1 (AF342732); EEV (AY026486); VR-299 (AF343572); WB (AF342727); C2 (AF342733); Sp (AF342728); Ab (AF342729); C3 (AF342734); Te (AF342731)

Table 2. Percent similarity and divergence of the amino acid sequences of the $1179 \mathrm{bp}$ cDNA fragment within the VP2 coding region of aquatic birnaviruses. Upper triangle indicates percent similarity; lower triangle indicates percent divergence. $\mathrm{Ja}=$ Jasper-ATCC, Ja-D = Jasper-Dobos, Ja-R = Jasper isolate which is resistant to RTS, Ja-S = Jasper isolate which is sensitive to RTS

\begin{tabular}{|c|c|c|c|c|c|c|c|c|c|c|c|c|c|c|c|c|}
\hline Virus & $\mathrm{Ab}$ & ASV & EEV & $\mathrm{He}$ & Ja & Ja-D & Ja-R & Ja-S & N1 & $\mathrm{Sp}$ & $\mathrm{Te}$ & VR-299 & WB & $\mathrm{C} 1$ & $\mathrm{C} 2$ & C3 \\
\hline $\mathrm{Ab}$ & $* *$ & 88.8 & 95.9 & 83.7 & 88.8 & 90.3 & 87.0 & 88.8 & 89.8 & 90.3 & 89.3 & 90.3 & 90.3 & 89.3 & 87.5 & 88.5 \\
\hline ASV & 12.2 & $* *$ & 89.3 & 82.1 & 86.5 & 87.8 & 95.9 & 86.5 & 88.8 & 89.3 & 95.2 & 87.8 & 87.0 & 97.7 & 87.0 & 87.5 \\
\hline EEV & 4.2 & 11.6 & ${ }^{* *}$ & 84.9 & 87.0 & 88.0 & 87.8 & 87.0 & 91.1 & 91.1 & 90.6 & 88.0 & 88.0 & 90.1 & 87.5 & 88.3 \\
\hline $\mathrm{He}$ & 18.5 & 20.5 & 16.8 & $* *$ & 82.9 & 83.7 & 81.9 & 82.9 & 87.2 & 87.8 & 84.4 & 83.7 & 82.9 & 83.2 & 83.7 & 82.9 \\
\hline $\mathrm{Ja}$ & 12.2 & 14.9 & 14.3 & 19.5 & ${ }^{* *}$ & 95.9 & 86.5 & 99.5 & 87.2 & 88.3 & 87.8 & 95.9 & 95.9 & 87.2 & 88.3 & 87.8 \\
\hline Ja-D & 10.4 & 13.4 & 13.1 & 18.5 & 4.2 & ${ }^{* *}$ & 87.0 & 95.9 & 88.3 & 89.3 & 88.0 & 99.5 & 97.2 & 88.5 & 88.3 & 88.3 \\
\hline Ja-R & 14.3 & 4.2 & 13.4 & 20.8 & 14.9 & 14.3 & ${ }^{* *}$ & 86.5 & 87.2 & 87.8 & 93.6 & 87.2 & 86.2 & 96.7 & 85.7 & 86.2 \\
\hline Ja-S & 12.2 & 14.9 & 14.3 & 19.5 & 0.5 & 4.2 & 14.9 & ${ }^{* *}$ & 87.2 & 88.3 & 87.8 & 95.9 & 95.9 & 87.2 & 88.3 & 87.8 \\
\hline N1 & 11.0 & 12.2 & 9.5 & 14.0 & 14.0 & 12.8 & 14.0 & 14.0 & ${ }^{* *}$ & 98.0 & 89.8 & 88.3 & 87.8 & 89.5 & 89.5 & 88.8 \\
\hline Sp & 10.4 & 11.6 & 9.5 & 13.4 & 12.8 & 11.6 & 13.4 & 12.8 & 2.1 & ${ }^{* *}$ & 89.8 & 89.3 & 88.8 & 90.1 & 89.3 & 88.5 \\
\hline $\mathrm{Te}$ & 11.6 & 5.0 & 10.1 & 17.5 & 13.4 & 13.1 & 6.7 & 13.4 & 11.0 & 11.0 & ${ }^{* *}$ & 88.0 & 87.8 & 95.4 & 88.0 & 88.0 \\
\hline VR-299 & 10.4 & 13.4 & 13.1 & 18.5 & 4.2 & 0.5 & 14.0 & 4.2 & 12.8 & 11.6 & 13.1 & ${ }^{* *}$ & 97.2 & 88.5 & 88.3 & 88.3 \\
\hline WB & 10.4 & 14.3 & 13.1 & 19.5 & 4.2 & 2.9 & 15.3 & 4.2 & 13.4 & 12.2 & 13.4 & 2.9 & ${ }^{* *}$ & 87.8 & 88.0 & 87.5 \\
\hline C1 & 11.6 & 2.3 & 10.7 & 19.1 & 14.0 & 12.5 & 3.4 & 14.0 & 11.3 & 10.7 & 4.7 & 12.5 & 13.4 & ${ }^{* *}$ & 88.5 & 89.0 \\
\hline $\mathrm{C} 2$ & 13.7 & 14.3 & 13.7 & 18.5 & 12.8 & 12.8 & 15.9 & 12.8 & 11.3 & 11.6 & 13.1 & 12.8 & 13.1 & 12.5 & $* *$ & 97.2 \\
\hline C3 & 12.5 & 13.7 & 12.8 & 19.5 & 13.4 & 12.8 & 15.3 & 13.4 & 12.2 & 12.5 & 13.1 & 12.8 & 13.7 & 11.9 & 2.9 & ${ }^{* *}$ \\
\hline
\end{tabular}


coupled with low repair rates do not always induce rapid evolution. Wild-type virus can predominate through an extensive passage history even though one variant can be dominant at any one time by immunological selection (Schiappacassi et al. 1995).

It has been reported that IPNV is highly heterogeneous at the genome level (Heppell et al. 1992, 1993, Zhang \& Suzuki 2003). In this study, we demonstrated the heterogeneity in clones of IPNV-Jasper. The parental virus, ATCC VR-1325 ('Jasper', prototype of the $A_{9}$ serotype of Hill \& Way 1995) was chosen due to its sensitivity to inactivation by normal RTS. Clones of this strain varied considerably in their sensitivity to RTS, with $8 \%$ exhibiting total resistance to inactivation by RTS. The deduced amino acid sequences of the VP2 region of the sensitive clones (Ja-S) had high sequence

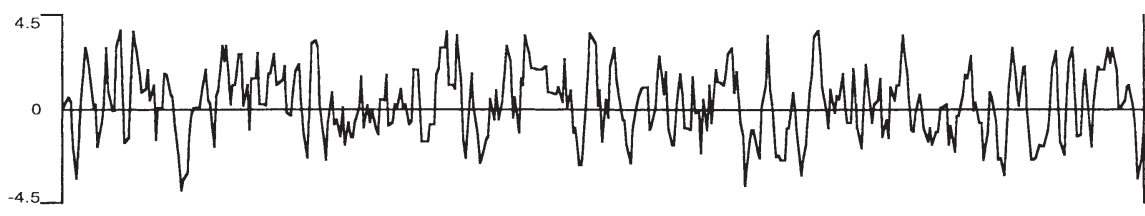

Hydrophilicity plot

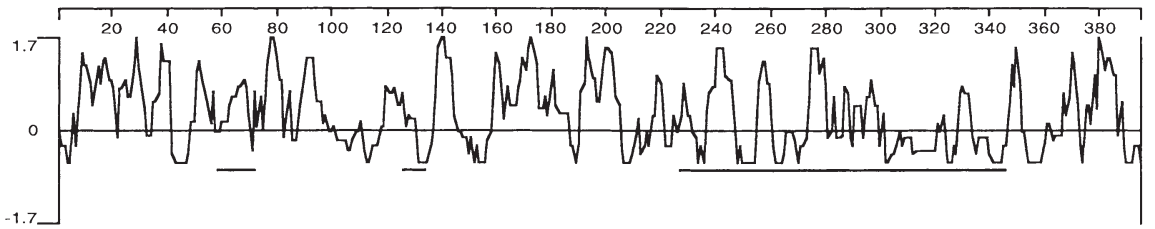

a

Antigenic index

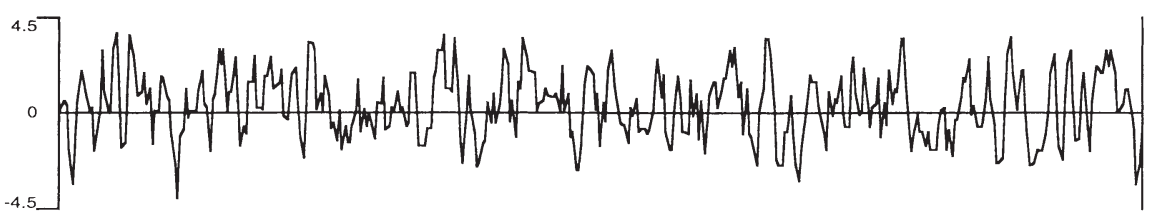

Hydrophilicity plot

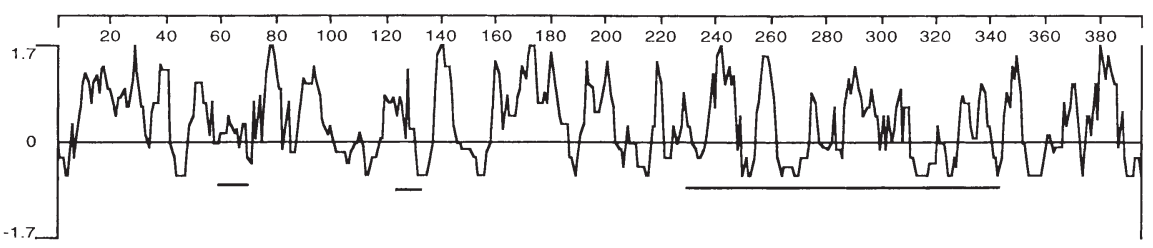

b

Antigenic index

Fig. 3. Hydrophilicity plots and antigenic index of amino acid sequences of VP2 from 2 IPNV-Jasper strains. (a) Jasper RTSsensitive strain; (b) RTS-resistant strain. Hydrophilicity plots were determined by the Kyte-Doolittle method. Antigenic indexes were determined by the James-Wolf method. Horizontal ruler represents the amino acid position. Lines under the antigenic index show the major antigenic differences between the RTS-sensitive and the RTS-resistant strain

Table 3. Monoclonal reaction patterns of IPNV in an immunodot assay. Jasper-parent $=$ parent IPNV-Jasper; Jasper-RTS-S = progeny Jasper-RTS sensitive clones; Jasper-RTS-R = progeny Jasper-RTS resistant clones

\begin{tabular}{|c|c|c|c|c|c|c|c|c|c|c|c|c|}
\hline \multirow[t]{2}{*}{ IPNV-isolate } & \multicolumn{11}{|c|}{ - Monoclonal antibodies (epitopes) } & \multirow[t]{2}{*}{ RTS sensitivity } \\
\hline & AS-1 & $\mathrm{W}-1$ & $\mathrm{~W}-2$ & $\mathrm{~W}-3$ & W-4 & W-5 & E-1 & E-2 & E-3 & E-5 & E-6 & \\
\hline Jasper-ATCC & + & + & + & + & + & + & + & - & - & + & - & Sensitive \\
\hline Jasper-parent & + & + & + & + & + & + & + & - & - & + & - & Sensitive \\
\hline Jasper-RTS-S & + & + & + & + & + & + & + & - & - & + & - & Sensitive \\
\hline Jasper-RTS-R & + & - & - & - & - & - & + & - & - & + & + & Resistant \\
\hline VR-299 & + & - & - & + & + & + & + & - & - & + & + & Resistant \\
\hline West Buxton & + & + & + & + & + & + & + & - & - & + & + & Resistant \\
\hline $\mathrm{Ab}$ & + & + & + & - & - & - & + & + & - & + & + & Resistant \\
\hline Canada 1 & + & - & - & - & - & - & + & + & - & + & + & Sensitive \\
\hline Canada 2,3 & + & - & - & - & - & - & - & - & - & + & + & Resistant \\
\hline Buhl $^{\mathrm{a}}$ & - & - & + & - & + & + & + & - & - & + & + & Resistant \\
\hline Epitope on: & VP-2 & VP-2 & VP-2 & VP-2 & VP-2 & VP-3 & VP-3 & VP-3 & VP-2 & VP-3 & VP-3 & \\
\hline
\end{tabular}


identity with our ATCC VR-1325. Analysis of the same region for the resistant clones (Ja-R) showed highest identity with the ASV and Canada 1 ( $\mathrm{A}_{6}$ serotype) isolates. Our phylogenetic study of the VP2 region and the results of our monoclonal reaction tests suggest that Ja-R is not closely related to either the parent strain or Ja-S strains.

It has been found that the epitope patterns of IPNV proteins, VP2 and VP3, have been stable during multiple viral passages in vivo and in vitro over long periods of time. For example, viruses (ATCC VR-877) isolated between 1970 and 1999 from chronically infected brook trout at a single facility were identical in their epitope pattern with 11 monoclonal antibodies (Reno 1999). Likewise, virus isolated from rainbow trout from the mid-1960s until 1999 at a rearing facility in the Idaho had an epitope pattern identical to ATCCVR1430 (Buhl) (Reno 1999). However, these antigenic tests have not been conducted for clones of virus populations. In this study, we report significant heterogeneity among clones with respect to epitope configuration and RTS sensitivity. From a total of 50 clones, $92 \%$ were wild-type (Ja-S) with respect to RTS sensitivity. For the 11 epitopes tested, these clones had all 8 of the epitopes that test positive in the ATCC VR-1325. Eight percent of the isolated clones (Ja-R) were resistant to RTS and these clones had an epitope configuration most similar to the $\mathrm{A}_{7}$, Canada 1 serotype. The Ja$\mathrm{R}$ strain differed from the Canada 1 serotype because it lacked the E-2 epitope. However, the presence of the E-2 epitope has been reported to be variable in the Canada 1 serotype (P. W. Reno unpubl. data). This suggests that the Ja-R strain is antigenically similar to the Canada 1 serotype. This is further supported by growth studies in different cell lines. The Ja-R strain was able to replicate in CHSE-214 but not in EPC cells. This pattern of growth is similar to that reported for Canada 1 by Ögüt (1995). The monoclonal reaction pattern of strain Ja-R is identical to that of IPNV-NEL that belongs to the Canada 1 serotype (P. W. Reno unpubl. data).

Based on the results of our RTS selection and subsequent sequence analysis, and monoclonal antibody tests of our Ja-S and Ja-R clones, it appears that the initial isolate (Jasper-parent) used in this study was heterogeneous.

The presence of the Ja-R strain within the VR-1325 might be accounted for by the exogenous contamination with a Canada 1 serotype isolate. The likelihood of exogenous contamination is small, since our lab has not used the IPNV-NEL isolate for the last $5 \mathrm{yr}$, including the time during which this experiment was carried out and the viruses were not thawed simultaneously even at that titre. The presence of heterologous IPNV in the Albertan hatchery at the time of the original iso- lations cannot be ruled out. Two laboratories obtained isolates of IPNV that they designated as 'Jasper' from the Maligne River hatchery at different times. These isolates are now referred to as Ja-D and Ja-ATCC. Berthiaume et al. (1992) reported that Ja-D and JaATCC showed differences in their monoclonal reaction patterns and sequences of their VP2 regions. In facilities with long-term, chronic IPN infection, it is recognized that multiple serotypes of IPNV can be present at a single facility. For example, 4 subtypes of IPNV ( $\mathrm{A}_{9}$ OR $A_{1}$, Buhl $A_{1}, A_{3}$ ) were isolated between 1986 and 1996 from a single facility in northern Idaho (Reno 1995). In 1990 alone, 3 serotypes were isolated from this facility. Two different subtypes were isolated from rainbow trout (VR-299) in 1975 and brook trout (Buhl) in 1974 at the Wizard Falls Hatchery in Oregon (P. W. Reno pers. comm.). Yamamoto (1975a,b) also reported that both rainbow and brook trout were found to harbor IPNV at Maligne River Hatchery, Alberta and the possibility exists that different sero/phenotypes were present. If this were indeed the case, the replication rates of the strains would have to have been very similar to prevent 1 strain from out competing the others. It is also possible that the Ja-R strain has always been present in this isolate at a level below the detection limit for the monoclonal antibodies.

There is some precedent for a genetic shift under the influence of selective pressure. Schiappacassi et al. (1995) reported polyclonal antibody neutralizationresistant $(\mathrm{Nr})$ variants from a population of footand-mouth disease virus $\mathrm{C}_{3}$ Resende strain. Resende original strain $\left(\mathrm{C}_{0}\right)$ was passaged 25 times under immunological pressure $\left(\mathrm{F}_{1}, \mathrm{~F}_{2}, \mathrm{~F}_{3}, \mathrm{~F}_{4}\right.$ and $\left.\mathrm{F}_{5}\right)$ or under non-immune pressure as a control $\left(\mathrm{C}_{1}, \mathrm{C}_{2}, \mathrm{C}_{3}\right)$. Each of the selected $\mathrm{Nr}$ populations $\left(\mathrm{F}_{1}\right.$ to $\left.\mathrm{F}_{5}\right)$ showed a specific antigenic reactivity. Three $\mathrm{Nr}$ variants $\left(\mathrm{F}_{2}, \mathrm{~F}_{3}\right.$ and $\mathrm{F}_{4}$ ) acquired 1 reactivity with monoclonal antibody (MAb) which was not positive from the original strain. The $\mathrm{F}_{1} \mathrm{Nr}$ population lost $1 \mathrm{MAb}$ reaction, while all other Nr variants as well as the control showed a positive reaction. Nucleotide sequence analysis from $\mathrm{Nr}$ variants and the original strain also showed modifications in the most variable regions (residues 40-60) of VP1.

Wang (1992) reported monoclonal antibody neutralization-resistant variants from a population of IPNVWest Buxton strain (WB). Two WB variant strains were very different from the parent based on genomic data and serotype; neutralization-resistant strains had diverged from $\mathrm{WB}$ and more closely resembled members of the $\operatorname{Sp}\left(\mathrm{A}_{2}\right)$ serotypes. Neutralization-resistant strains shared less than $80 \%$ sequence homology with WB strains.

We found VR-1325 and Ja-S had the same monoclonal reaction pattern (Table 3). If the parental IPNV- 
Jasper contained a subpopulation of $8 \%$ of Ja-R variants, E-6 monoclonal antibody reaction might be expected to be positive since Ja-R has the epitope, whereas Ja-ATCC does not. So the question arose whether all Ja-R had the same epitope pattern, including E-6. We tested all 4 Ja-R clones and found that all showed the same epitope pattern (data not shown). Originally the concentration of Ja-parent tested for serotyping was $10^{7} \mathrm{TCID}_{50} \mathrm{ml}^{-1}$, thus if the Ja-R strain comprised $8 \%$ of the population, the concentration of Ja-R would have been approximately $10^{6} \mathrm{TCID}_{50} \mathrm{ml}^{-1}$. We found that a reaction with E-6 was not positive at a concentration of $10^{6} \mathrm{TCID}_{50} \mathrm{ml}^{-1}$. Our laboratory experience has shown that Ja-ATCC does not generally grow to a high titer (approximately $10^{7} \mathrm{TCID}_{50} \mathrm{ml}^{-1}$ ), compared to other serotypes (approx. $10^{10} \mathrm{TCID}_{50} \mathrm{ml}^{-1}$ ) (Ögüt 1995, P. W. Reno unpubl. data). For the serotyping of Ja-R, the clones were passaged once more in RTG-2 cells in the presence of RTS and the virus titer was significantly elevated $\left(10^{9}\right.$ to $\left.10^{10} \mathrm{TCID}_{50} \mathrm{ml}^{-1}\right)$ and produced a strong monoclonal reaction at E-6. This elevated virus titer of the Ja-R clones may have been inhibited when Ja-S was present in the mixture originally. It is known that parental wild-type RNA phage consistently outgrew variant clones under normal in vitro conditions (Domingo et al. 1978). Maret (1997) also found that one type of IPNV (Buhl) outgrew another type of IPNV (WB) in a superinfection experiment in brook trout. However, the stability between wild-type and variant virus could be changed by some condition such as interference by defecting interfering (DI) particles, different host or cell types, or immune selection (Steinhauer \& Holland 1987) and thereby enhance the replication of a normally slower replicating virus. It is known that host immune selection can be a strong factor in driving virus evolution (Clements et al. 1980, Palese \& Young 1982, Webstrer et al. 1982). Even though we do not know the whole history of the Jasper-isolate (Ja-ATCC) that was used in this experiment, we passaged the virus 2 times through brook trout just before this experiment, which could select more RTS-resistant strains from the virus population. Even though a 1:100 dilution of brook trout serum (as opposed to RTS) did not significantly inhibit the virus in vitro (Park 2000), this could still be one of the possible reasons that a RTS-resistant population could emerge and comprise a relatively high proportion of the clones $(8 \%)$ in vitro.

We found Ja-R had an epitope composition most closely related to the Canada 1 serotype and had highest amino acid homology with genogroup 4, as reported by Blake et al. (2001), which is also the Canada 1 clade (Tables $2 \& 3$ ). Based on 11 monoclonal reaction patterns, we could not differentiate between the
RTS-sensitive and RTS-resistant strain. All of the RTSresistant strains tested showed a positive reaction for E-6 MAb and a negative reaction for W5 MAb. The Canada 1, sensitive isolate, also showed a similar reaction for 2 MAbs. Buhl, a resistant isolate, however had a positive reaction for W5 MAb. It is more likely that other epitopes which do not react with these 11 MAbs are more closely linked to RTS sensitivity.

The antigenic differences between ATCC VR-1325 and Ja-R might not be directly tied to amino acid sequence, but might also be associated with glycosylation of the VP2 or VP3. Glycosylation as well as proper folding of the protein are important factors in antigenicity (Caust et al. 1987). Even though contradictory results have been noted (Perez et al. 1996, B. L. Nicholson pers. comm.), the possibility of glycosylation in IPNV has been suggested (Estay et al. 1990, Håvarstein et al. 1990, Hjalmarsson et al. 1999, Espinoza et al. 2000). To date, 2 possible glycosylation sites, N-glycosylation (Estay et al. 1990) and O-glycosylation (Hjalmarsson et al. 1999), have been suggested. In this study, possible glycosylation sites for Nglycosylation and O-glycosylation were deduced from amino acid sequences of 2 IPNV-Jasper strains. The 2 strains had the same number of possible N-glycosylation sites, Asn(N)-X-Ser(S)/Thr(T) (Fig. 1). Three sites were present on the same regions of 2 strains $(63-65,108-110,224-225)$; however, the possible sites at 63-65 had different hydrophilic characteristics: Ja-S was hydrophilic at this region and Ja-R was not. The last possible site was present at different regions: Ja-S amino acids $242-244$ was a hydrophilic region, while Ja-R amino acids 233-235 were not hydrophilic. The 2 strains had similar numbers of possible O-glycosylation sites involving the amino acids, Ser or Thr. The RTS-sensitive strain had 69 possible sites, while Ja-R had 72 sites among 394 amino acid residues. Ja-S had 14 possible O-glycosylation sites on hydrophilic residues, while Ja-R had 10 sites. This indicates that the Ja-S strain has more possible glycosylation sites for both N-glycosylation and O-glycosylation on hydrophilic regions than Ja-R does. However, we need more data to determine the glycosylation of IPNV.

In conclusion, IPNV-Jasper variants (Ja-R) isolated from IPNV-Jasper (Ja-ATCC) which are sensitive to RTS were resistant to RTS and different with respect to the serotype, and cDNA sequence of VP2 coding region.

Acknowledgements. We would like to thank the personnel in the Fish Disease Lab of Oregon Department of Fish and Wildlife for their kind support. The authors thank Dr. S. Johnson at the Institute for Marine Biosciences for his review of the manuscript. This research was funded from the National Sea Grant (NOAA88-204) and supported by the Mamie Markham Fund. 


\section{LITERATURE CITED}

Berthiaume L, Tarrab E, Heppell J, Arella M, Dobos P, Duncan R, Lecomte J (1992) Antegenic and genomic differences of two Jasper strains of infectious pancreatic necrosis virus. Intervirology 34:197-201

Blake S, Ma JY, Caporale DA, Jairath S, Nicholson BL (2001) Phylogenetic relationships of aquatic birnaviruses based on deduced amino acid sequences of genome segment A cDNA. Dis Aquat Org 45:89-102

Caswell-Reno P, Reno PW, Nicholson BL (1986) Monoclonal antibodies to infectious pancreatic necrosis virus: analysis of viral epitopes and comparison of different isolates. J Gen Virol 67:2193-2205

Caswell-Reno P, Lipipun V, Reno PW, Nicholson BL (1989) Utilization of a group reactive and other monoclonal antibodies in an enzyme immunodot assay for identification and presumptive serotyping of aquatic birnaviruses. J Clin Microbiol 27:1924-1929

Caust J, Dyall-Smith ML, Lazdins I, Holmes IH (1987) Glycosylation, an important modifier of rotavirus antigenicity. Arch Virol 96:123-134

Christie KE, Håvarstein L, Djupvik HO, Ness S, Endresen C (1988) Characterization of a new serotype of infectious pancreatic necrosis virus isolated from Atlantic salmon. Arch Virol 103:67-77

Clements JE, Narayan O, Griffin DE, Johnson RT (1980) Genomic changes associated with antigenic variation of visna virus during persistent infection. Proc Natl Acad Sci USA 77:4454-4458

Dobos P (1995) The molecular biology of infectious pancreatic necrosis virus (IPNV). Annu Rev Fish Dis 5:25-54

Dobos P, Rowe D (1977) Peptide map comparison of infectious pancreatic necrosis virus-specific polypeptides. J Virol 24: 805-820

Dobos P, Hallet R, Kells DTC, Sorenson O, Rowe D (1977) Biopysical studies of infectious pancreatic necrosis virus. J Virol 22:150-159

Dobos P, Hill BJ, Hallett R, Kells DTC, Becht H, Teninges D (1979) Biophysical and biochemical characterization of five animal viruses with bisegmented dsRNA genomes. J Virol 32:593-605

Domingo E, Sabo D, Taniguchi T, Weissmann C (1978) Nucleotide sequence heterogeneity of an RNA phage population. Cell 13:735-744

Domingo E, Dávilla M, Ortín J (1980) Nucleotide sequence heterogeneity of the RNA from a natural population of foot-and-mouth disease virus. Gene 11:333-346

Dorson M, de Kinkelin P (1974) Necrose pancreatique infectieuse des salmonides: existence dans le serum de truites indemnes d'une molecule $6 \mathrm{~S}$ neutralisant specifiquement le virus. C R Acad Sci Paris Ser D 278:785-788

Dorson M, Castric J, Torchy C (1978) Infectious pancreatic necrosis virus of salmonids. Biological and antigenic features of a pathogenic strain and a nonpathogenic variant selected in RTG-2 cells. J Fish Dis 1:309-320

Duncan R, Dobos P (1986) The nucleotide sequence of infectious pancreatic necrosis virus (IPNV) dsRNA segment A reveals one large ORF encoding a precursor polyprotein. Nucleic Acids Res 14:5934

Duncan R, Nagy E, Krell PJ, Dobos P (1987) Synthesis of the infectious pancreatic necrosis virus polyprotein, detection of a virus-encodes protease, and fine structure mapping of genome segment A coding regions. J Virol 61:3655-3664

Espinoza JC, Hjalmarsson A, Everitt E, Kuznar J (2000) Temporal and subcellular localization of infectious pancreatic necrosis virus structural proteins. Arch Virol 145:739-748
Estay A, Farias G, Soler M, Kuznar J (1990) Further analysis on the structural proteins of infectious pancreatic necrosis virus. Virus Res 15:85-96

Håvarstein LS, Kalland KH, Christie KE, Endresen C (1990) Sequence of the large double-stranded RNA segment of the N1 strain of infectious pancreatic necrosis virus: a comparison with other Birnaviridae. J Gen Virol 71: 299-308

Heppell J, Berthiaume L, Tarrab E, Lecomte J, Arella M (1992) Evidence of genomic variations between infectious pancreatic necrosis virus strains determined by restriction fragment profiles. J Gen Virol 73:2863-2870

Heppell J, Berthiaume L, Corbin F, Tarrab E, Lecomte J, Arrella M (1993) Comparison of amino acid sequences deduced from a cDNA fragment from infectious pancreatic necrosis virus (IPNV) strains of different serotypes. Virology 195:840-844

Hill BJ (1982) Infectious pancreatic necrosis virus and its virulence. In: Roberts RJ (ed) Microbiol diseases of fish. Academic Press, London, p 91-114

Hill BJ, Dixon PF (1977) Studies on IPN virulence and immunization. Bull Off Int Epizoot 85:425-427

Hill BJ, Way K (1995) Serological classification of infectious pancreatic necrosis (IPN) virus and other aquatic birnavirus. Annu Rev Fish Dis 5:55-77

Hjalmarsson A, Carlemalm E, Everitt E (1999) Infectious pancreatic necrosis virus: identification of a VP3-containing ribonucleoprotein core structure and evidence for Olinked glycosylation of the capsid protein VP2. J Virol 73: 3484-3490

Kelly RK, Nielsen O (1985) Inhibition of infectious pancreatic necrosis virus by serum from normal rainbow trout (Salmo gairdneri) in Canadian hatchery. Fish Pathol 19:245-251

Lannan CN, Winton JR, Fryer J (1984) Fish cell lines: establishment and characterization of nine cell lines from salmonids. In Vitro 20:671-676

Lee SJ, Wang-Buhler JL, Cok I, Yu TS, Yang YH, Miranda CL, Lech J, Buhler DR (1998) Cloning, sequencing, and tissue expression of CYP3A27, a new member of the CYP3A subfamily from embryonic and adult rainbow trout livers. Arch Biochem Biophys 360:53-61

MacDonald RD, Dobos P (1981) Identification of the proteins encoded by each segment of infectious pancreatic necrosis virus. Virology 114:414-422

MacDonald RD, Gower DA (1981) Genomic and phenotypic divergence among three serotypes of aquatic birnaviruses (Infectious pancreatic necrosis virus). Virology 114: $187-195$

Maret JJ (1997) Virulence characteristics of infectious pancreatic necrosis virus (IPNV) in brook trout, Salvelinus fontinalis, fry. MSc thesis, Oregon State University, Corvallis, OR

Mertens P, Dobos P (1982) Messenger RNA of infectious pancreatic necrosis virus is polycistronic. Nature 297:243-246

Nicholson B (1993) Use of monoclonal antibodies in identification and characterization of fish viruses. Annu Rev Fish Dis 3:241-257

Ögüt H (1995) In vitro host range of aquatic birnaviruses and their relationship to virulence. MSc thesis, Oregon State University, Corvallis, OR

Palese P, Young JF (1982) Variation of influenza A, B and C viruses. Science 215:1468-1474

Park KC (2000) Characterization of an inhibitor ('6S') of infectious pancreatic necrosis virus (IPNV) in normal rainbow trout serum (RTS) and its effects on the virus. PhD thesis, Oregon State University, Corvallis, OR

Perez L, Chiou P, Leong J (1996) The structural proteins of 
infectious pancreatic necrosis virus are not glycosylated. J Virol 70:7247-7249

Reno PW (1995) Infectious pancreatic necrosis virus: Whither goes thou? Aquatic birnaviruses in the United States: an historical and serological perspective. American Fisheries Society/Fish Health Section Annual Meeting, Syracuse, NY, Abstract \#19

Reno PW (1999) Infectious pancreatic necrosis and associated aquatic birnaviruses. In: Woo PTK, Bruno DW (eds) Fish diseases and disorders, Vol 3. Viral, bacterial and fungal infections. CABI Publishing, New York, p 1-55

Schiappacassi M, Rojas ER, Carrillo E, Campos R (1995) Response of foot-and-mouth disease virus C3 Resende to immunological pressure exerted in vitro by antiviral polyclonal sera. Virus Res 36:77-85

Spearman C (1908) The method of 'right and wrong cases' (Constant Stimuli) without Gauss's formulae. Br J Psychol 2:227-234

Steinhauer DA, Holland JJ (1987) Rapid evolution of RNA viruses. Annu Rev Microbiol 41:409-433

Steinhauer DA, de la Torre CJ, Meier E, Holland JJ (1989) Extreme heterogeneity in population of vesicular stomatitis virus. J Virol 63:2072-2080

Vestergard-Jørgensen PE (1973) The nature and biological activity of IPN virus neutralizing antibodies in normal and

Editorial responsibility: Jo-Ann Leong,

Kaneohe, Hawaii, USA immunized rainbow trout (Salmo gairdneri). Arch Ges Virusforsch 42:9-20

Wang SH (1992) Investigation of antigenic and host range variation among aquatic birnaviruses using monoclonal antibody neutralization-resistant variants. $\mathrm{PhD}$ thesis, University of Maine, Orono, ME

Webster RG, Laver WG, Air GM, Schild GC (1982) Molecular mechanism of variation in influenza viruses. Nature 196: $115-121$

Wolf K, Quimby MC (1962) Established eurythermic cell line of fish cell in vitro. Science 135:1060-1066

Yamamoto $T$ (1974) Infectious pancreatic necrosis virus occurrence at a hatchery in Alberta. J Fish Res Board Can 31:397-402

Yamamoto T (1975a) Frequency of detection and survival of infectious pancreatic necrosis virus in carrier population of brook trout (Salvelinus fontinalis) in a lake. J Fish Res Board Can 32:568-570

Yamanoto T (1975b) Infectious pancreatic necrosis (IPN) virus carriers and antibody production in a population of rainbow trout (Salmo gairdneri). Can J Microbiol 21: $1343-1347$

Zhang CX, Suzuki S (2003) Comparison of the RNA polymerase genes of marine birnavirus strains and other birnaviruses. Arch Virol 148:745-758

Submitted: January 20, 2003; Accepted: June 3, 2004

Proofs received from author(s): October 22, 2004 